\title{
What the City Has to Offer: Urbanization and Women's Empowerment in Turkey
}

\section{Kursat Cinar}

\section{Bilkent University}

\section{Meral Ugur-Cinar}

\section{Bilkent University}

This article analyzes the prospects and limits of urbanization for women's
empowerment. To do so, it looks at a case, Turkey, that can provide us with valuable insights into this issue. Turkey is a country that has experienced rapid urbanization since the 1970s. Its urban landscape has been transformed ever since. Turkey also provides a special case as it is a predominantly Muslim country in which women gained major political rights early on, even before many of their Western counterparts. Turkish women were granted equal rights of divorce, inheritance, and child custody as early as 1926, three years after the Turkish Republic was proclaimed. They earned suffrage rights in local elections (1930) and in national elections (1934). Yet, in contrast to the public rights acquired, gender inequality in the private sphere has remained mostly intact. The domestic

\footnotetext{
The authors acknowledge the financial support of the European Union (Horizon 2020 - Marie Curie Reintegration Project: "Female Empowerment" - Project \# 702073) and the Scientific and Technological Research Council of Turkey (TÜBITTAK) (H2020 Success Award \# 342617). They also would like to thank all survey participants in their research, including members of the Federation of Women's Organizations in Turkey (Türkiye Kadın Dernekleri Federasyonu), Women Entrepreneurs Association of Turkey (Türkiye Kadın Girişimciler Derneği), Uçan Süpürge, Women's Cooperatives Association (Kadın Kooperatifleri Birliği), Union of Chambers of Turkish Engineers and Architects (Türk Mühendis ve Mimar Odaları Birliği). They also thank the three anonymous reviewers and the journal editor for their helpful comments on previous drafts.
}

Published by Cambridge University Press 1743-923X/18 \$30.00 for The Women and Politics Research Section of the American Political Science Association.

(C) The Women and Politics Research Section of the American Political Science Association, 2018 doi:10.1017/S1743923X18000028 
realm has been predominantly viewed as the primary domain of women (Kandiyoti 1982, 1987). To illustrate, we can cite the following examples: until 2002, the Turkish Civil Code designated the husband as the head of the family and gave rights to him accordingly ${ }^{1}$; until recently, women needed to take their husband's surname in addition to their own $^{2,3}$; and a woman's record in the population register is placed under her husband's family register after marriage ${ }^{4}$ (for more on this issue, see Ugur-Cinar 2014).

Turkish women face further challenges as the governing Justice and Development Party (AKP) is ruling with a new mode of patriarchy that blends sociocultural conservatism with neoliberalism (Coşar and Yeğenoğlu 2011, 555). That is to say, under the current political atmosphere, women are threatened by two phenomena. On the one hand, women are seen as solely familial creatures, and feminist demands are constantly undermined. On the other hand, neoliberal policies cause insecure and informal working conditions for women (Buğra 2014; Coşar and Yeğenoğlu 2011).

How have sociocultural transformations, particularly urbanization, affected the conditions of Turkish women within this context? What do standard empowerment indicators have to tell us about this relationship? Are these changes in the empowerment indicators reflected in the actual lives of Turkish women? To address these questions, the article employs a twopronged approach. In a province-level statistical analysis, the article tests the overall impact of urbanization on women's empowerment by tapping into educational, economic, and political indicators. Then, the article uses extensive original survey data to examine the extent to which the results found in the quantitative section are paralleled by the actual experiences of Turkish women. The survey specifically targets highly educated, urban women. The reason for such a sampling strategy is to test the limits of what urbanization can offer to Turkish women by understanding the prospects for these women along with the challenges they face.

1. Türk Medeni Kanunu (Turkish Civil Code), February 17, 1926, Law No.743, Official Gazette No. 339, April 4, 1926.

2. This issue is still not fully resolved. The issue of women keeping their maiden surname has only made progress with the European Court of Human Rights' decision in 2004, and even the domestic adoption of this decision took almost a decade. In 2013, the Constitutional Court accepted that women could use their maiden surname on the basis of the European Court of Human Rights decision (Official Gazette, January 7, 2014, No. 28875). It has been rightly maintained that we need further domestic laws bringing this issue to certainty; otherwise, women will keep applying to courts to make their case (Karakaş 2016).

3. Turkish Civil Code, November 22, 2001, Law No. 4721, Official Gazette No. 24607, August 12, 2001.

4. Nüfus Hizmetleri Kanunu (Law on Population Registration), April 25, 2006, Law No. 5490, Official Gazette No. 2 6153, April 29, 2006. 
As the literature on intersectionality has demonstrated, patriarchy affects different groups of women differently as it is linked with other forms of subordination based on issues such as class, ethnicity, race, and colonialism (Mann 2012; Patil 2013). Intersectionality recognizes that individuals with diverse ethnic, religious, or racial identities face discrimination on multiple grounds (Choo 2012; Geerts and Van der Tuin 2013). The article thus focuses on a specific group of women to show how patriarchy is experienced by women of relatively higher class and better education living in urban settings. As will be elaborated in the following sections of the article, these women are the ones least likely to be hindered by their gender as they are expected to reap the benefits of urbanization such as education and economic freedom. The findings of this article will encourage further research on the barriers faced by women in the different strata of the society, such as those who belong to the intersecting membership of minority ethnicity and lower social class.

\section{URBANIZATION AND WOMEN'S EMPOWERMENT IN THE WORLD}

Based on the existing literature, this article defines women's empowerment as the process through which women acquire the ability to make strategic and effective life choices and come to use this ability effectively for positive change (Goldman and Little 2015, 763; Janssens 2009, 975; Kabeer 1999, 435; Moghadam 1996, 13). Women's empowerment cannot be viewed as a single-dimensional phenomenon (Chant and Datu 2015, 56; Goldman and Little 2015, 762-63). It is a multifaceted process that is experienced at the individual as well as the household and community levels. What is more, women's empowerment, or the lack thereof, can be observed in diverse areas of human life. To this end, the article focuses on three key subcomponents of women's empowerment: empowerment in education, economics, and politics. These three categories have been recognized as crucial aspects of women's empowerment in the relevant literature. They have also been included in the United Nations' Sustainable Development Goals for promoting gender equality and empowering women (UN 2015). To be sure, women's empowerment entails enhancements in other aspects of women's lives, including legal rights and reproductive rights. Yet limiting the scope of our research to empowerment in the areas of education, economics, and politics enables us to offer detailed analyses of the state of women's empowerment in these critical areas. Besides, as we will discuss 
later, enhancements in women's empowerment in our selected areas have the potential to have positive spillover effects to other aspects of women's lives.

The focus of our research on three major areas of women's empowerment sheds light on the concept at hand. To begin with, without education, women lack access to public resources and cannot sufficiently utilize their legal rights. Education increases the potential for women to become active participants in society and mobilize themselves (Moghadam 1998, 3). Chant (2013, 15) finds that "educated women, on average, delay marriage and childbirth, are less vulnerable to HIV/AIDS, enjoy more power in their homes and in public arenas and have fewer children, who also tend to be healthier and better educated." To this end, education is an integral aspect of women's "personhood," affecting their general capacities, self-esteem, and ability to exert agency (Chant and Datu 2015, 44).

Economic empowerment is also vital for women since it is significantly harder for women to escape abusive relationships without economic independence. It is true that women's economic participation "must be negotiated through familial bargaining and levering of power by degrees." (Afshar 1998, 3) In addition, striking a balance between work and home and frictions within households due to patriarchal gender roles can cause stress for women (Banks 2013, 99-103). Still, in many cases, throughout a diverse set of countries such as Chile, China, and Bangladesh, working provides women with considerable benefits, even though, as will be discussed later, the nature of the jobs needs to be taken into account as well. As Cindoğlu and Tokta? $(2002,37)$ maintain,

$[T]$ he advantages of working include: economic independence (the most important), social security, social productivity, opportunity for selfrealization, social environment outside the house, prestigious social status, opportunity to renew oneself, motivation to take care of oneself, quality mothering time for children, respect in marriage and more say in family affairs.

Based on a study conducted in Bangladesh, Banks (2013) argues that women's entry into the workforce and their increased mobilization shake (if not totally change) the patriarchal norms and beliefs and socially entrenched gender roles of many married couples (see also Hammad 2016, 13-14, on Egypt; Moghadam 1998, 91, on Turkey). Cindoğlu and Tokta? $(2002,44)$ also find that work enables single women to have a "powerful bargaining position vis-à-vis the institution of marriage." In a similar vein, Moghadam $(1996,4)$ maintains that the employment of women enables them to become autonomous human beings and 
contribute to social development beyond household responsibilities within the context of the Middle East and North Africa and beyond. Education and labor force participation are also mutually enforcing. Tansel $(2002,11)$ maintains that the most important personal variable influencing female labor force participation is the level of education, with the effect of education on female labor force participation increasing at higher education levels (see also Psacharopoulos and Tzannatos 1991).

Women's higher representation in local and national politics is crucial for women's empowerment at both the societal and household levels. Political power is essential for women's empowerment because it influences the allocation of resources in societies (Almeleh et al. 1993, 28-29). Women participating in politics also feel much less obliged or willing to silence themselves when they think that their husbands are making unwise decisions (Burnet 2011, 324). Women's representation in governmental bodies alters discriminatory assumptions and beliefs about the "ideal" profile of leaders and improves women's conviction in their ability to govern. The cognitive effect of women's political participation on other attitudes and values holds across many nations both culturally and developmentally (Alexander 2012, 441-42). All in all, women's heightened presence in education, economics, and politics surely makes an impact on women's empowerment.

The relationship between urbanization and women's empowerment has become a rich and contested field of research in development and feminist studies. Earlier modernization theories asserted that economic development accompanied by urbanization and industrialization affects both men and women positively (Inkeles and Smith 1974; Lerner 1958; Lipset 1959). This assertion has been supported by some later works and criticized by others. Inglehart and Norris (2003, 10) argue that modernization linked with economic development brings positive changes in cultural attitudes toward gender equality.

As Chant and Datu $(2015,41)$ state, feminist approaches to urbanization criticize the predominantly gender-blind approach of the studies of the city. On the other hand, Boserup (1970) claims that economic development does not automatically improve women's conditions. Similarly, Abadian (1996, 1793) criticizes the assertion that economic development, accompanied by urbanization and industrialization, affects both men and women positively on the grounds that women lag men in the "degree to which they have access to resources needed to attain a decent standard of living" (see also Chant 2013, 9; Chant and Datu 2015, 39). 
Delving into the effect of the nature of economic development on the status of women, Ross $(2008,107)$ maintains that "when growth encourages women to join the formal labor market, it ultimately brings about greater gender equality; when growth is based on oil and mineral extraction, it discourages women from entering the labor force and tends to exaggerate gender inequalities." In parallel, Moghadam (1998, 5, 23) claims that in the Middle Eastern context, the gender-specific effects of development, urbanization, and industrialization are often overlooked or treated as peripheral matters.

Urbanization has mixed effects on women's empowerment, facilitating it in some regards and harming it in others. Earlier works on the topic usually focused on the role of urbanization on female labor force participation (Elmas 2004; Goldin 1995; Pampel and Tanaka 1986; Tansel 2002). However, it is evident that urbanization has multiple repercussions on women's lives and their empowerment beyond economic participation. As a result of urbanization, women receive better education, are able to determine the number of children they have, and can invest in themselves and their children (Ashraf, Karlan, and Yin 2009, 333; Cindoğlu and Toktaş 2002, 32-37; Chant 2013, 13-15; Erman, Kalaycıoğlu, and Rittersberger-Tilıç 2002, 404-5; Eswaran 2002, 434). Women in cities usually have better access to a variety of civil society organizations (Goldman and Little 2015, 773; Janssens 2009, 974; Lind 1997, 1205-7; Wyndow, Li, and Mattes 2013, 37) and microfinance institutions ${ }^{5}$ (Ashraf, Karlan, and Yin 2009; Haile, Bock, and Folmer 2012; Kabeer 2001; Osmani 2007; Pitt and Khandker 1996; Weber and Ahmad 2014), which have the potential to empower them politically and economically.

Even though the general picture is optimistic about the impact of urbanization on women's empowerment, we should not jump to conclusions. First of all, urbanization influences different women differently. There is still a great difference among urban women with regard to their socioeconomic and political well-being. A significant number of women in urban places are still forced to stay at home as

5. There is no consensus on the role of microfinance institutions. While some (e.g., Ashraf, Karlan, and Yin 2009, 333) argue that it is a tool that can empower women, others (see Altan-Olcay 2014) are critical of microfinance institutions because they argue, for instance, that these institutions lead women to feel overwhelmed as a result of their dual roles as entrepreneurs and housewives. Further, others have argued that the success of such institutions is context specific. For example, Haile, Bock, and Folmer $(2012,257)$ argue that "the variation in results of microfinance programmes and the degree of empowerment achieved may be explained by differences in the socio-cultural or economic contexts or differences in institutional programme strategies." 
housewives and/or face domestic violence by their husbands and families. Among those women who enter the workforce, a large number of them work in temporary, low-paying, informal jobs that do not provide social security. Many women find these jobs through their families and relatives in their small environments, and many are paid much less than men who have the same merits and education (Erman, Kalaycıŏglu, and Rittersberger-Tilıç 2002; Chant 2013, 21; Chant and Datu 2015, 46; Mitra 2005, 291). Even urban women in better-off segments of society face serious challenges in education, the workplace, and politics (Buğra 2014, 150-52; Çınar 1994, 371; Kandiyoti 1988; Mitra 2005, 293). Even in countries where civil society participation is high, political participation of women is still very low (Charrad 2009, 551). A more nuanced look at the social, economic, and political factors that impede women empowerment in urban centers is thus vital to capturing the whole picture. By identifying these factors, we can discern how women can have their fair share in education, economic welfare, and political representation.

\section{URBANIZATION AND WOMEN'S EMPOWERMENT IN TURKEY: WHAT THE NUMBERS TELL US}

The World Bank underlines that each country defines what "urbanization" means and determines its urbanization levels accordingly. For the duration of our study, the Turkish Statistical Institute (TUIK) sets a population threshold of 20,000 for urbanization in Turkey; below this threshold, localities are called rural, whereas above it, they are deemed urban centers. ${ }^{6}$ The evolution of rural society to an urbanized one affects statesociety relations, including how women are situated in economic and political fronts (Kitschelt and Wilkinson 2007). In the Turkish case, there have been massive socioeconomic changes, one of the most influential of which is urbanization. According to the World Bank

6. Metropolitan Municipality Law No. 6360 (along with Law No. 5393 and No. 6447), enacted in 2014, made major alterations in the definition of "urban" and "rural" centers, in which the boundaries of prospective metropolitan urban centers were extended by incorporating rural areas with population under 2000 . This significantly increased the urbanization rate from $72 \%$ (the latest data we used in light of World Bank-TUIK) to $86 \%$. The revision of "rural" and "urban" based on this law forced the TUIK to postpone publishing urbanization data until a methodology is developed in light of the EUROSTAT norms (see the relevant official document (TUIK 2014a) and TUIK president's press conference criticizing the revision (Dogan News Agency 2014). Fortunately, our province-level urbanization data are based on 2013-14 period, which is prior to the enactment of the said law. 
Development Indicators, the percentage of the Turkish population that resides in urban centers has risen steadily over the decades, as shown in Table 1. According to the most recent figures, more than $72 \%$ of the Turkish population lives in urban centers.

To understand the relationship between urbanization and women's empowerment in Turkey, this article compiles data at the local level from TUIK, the Social Security Institution (SGK), the Ministry of Family and Social Policies, and the Ministry of Development. The unit of analysis is 81 provinces (for descriptive statistics, see Appendix A). Based on the most recent local-level data (either for 2013 or 2014), urbanization usually makes a positive impact on the general livelihoods of the Turkish people. As shown in Table 2, one-to-one (bivariate) relationships between urbanization and important livelihood indicators reveal important insights at the local level.

Urbanization has the biggest positive impact on education (cf. $R^{2}$ figures), as indicated by the positive and statistically very significant coefficient of the secondary school enrollment rates. A one-unit rise in urbanization at the province level increases secondary schooling by approximately 0.3 units. Urbanization also makes a positive impact on average life expectancy and net migration, whereas it decreases the average household size at the local level. Those who live in urban centers live longer; urban centers attract higher levels of net migration; and urbanites have fewer children and smaller families. On the other hand, province-level analysis reveals that urbanization is positively correlated with unemployment. In other words, urbanization tends to increase unemployment levels at the local level. It is evident that urbanization brings about opportunities and advantages on many fronts yet various challenges on others.

As Table 3 shows, there are discrepancies in annual employment income according to gender and rural-urban status. There is an income gap between men and women, both in urban and rural settings. Men earn around 4,000 Turkish liras (US\$2,000 according to the exchange rate of the relevant year) more than women. Both urban men and women earn considerably more than their rural counterparts. Men and women earn around 7,000 Turkish liras (US\$3,500) more in urban areas. Based on Tables 2 and 3, it is safe to argue that urbanization has positive effects on people's lives with regard to economic affluence, education, and life expectancy. Yet it may bring about new socioeconomic challenges such as increased levels of unemployment. 
Table 1. Urbanization trends in Turkey

\begin{tabular}{lccccccc}
\hline Urban population & 1960 & 1970 & 1980 & 1990 & 2000 & 2010 & 2014 \\
\hline \% of total population & 31.5 & 38.2 & 43.7 & 59.2 & 64.7 & 70.5 & 72.9 \\
\hline
\end{tabular}

Source: World Bank Development Indicators, 2016.

Table 2. The impact of urbanization at the local (province) level

\begin{tabular}{|c|c|c|}
\hline Dependent variable & $\begin{array}{c}\text { Coefficient } \\
\text { (SD) }\end{array}$ & Adjusted $R^{2}$ \\
\hline Secondary schooling & $\begin{array}{l}0.290^{\text {* }} \\
(0.054)\end{array}$ & 0.24 \\
\hline Life expectancy & $\begin{array}{l}0.020 \text { ** } \\
(0.009)\end{array}$ & 0.04 \\
\hline Net migration & 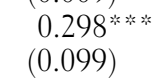 & 0.09 \\
\hline Average household size & 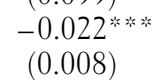 & 0.07 \\
\hline Unemployment & $\begin{array}{l}0.033^{*} \\
(0.014)\end{array}$ & 0.03 \\
\hline
\end{tabular}

Notes: Robust standard errors in parentheses. All of the regressions are done bivariately and at the province level $(N=81) .{ }^{* * * * *} p<.01 ;{ }^{* * * *} p<.05 ;{ }^{*} p<.10$.

Sources: TUIK, SGK, Ministry of Family and Social Policies, and Ministry of Development.

Table 3. Average annual employment income according to gender and rural/ urban status

\begin{tabular}{lccr}
\hline & Turkey & Urban & Rural \\
\hline Men & 18,125 & 20,083 & 13,501 \\
Women & 14,350 & 15,814 & 8,967 \\
\hline
\end{tabular}

Notes: All incomes are in Turkish liras (TL). Employment categories include full-time employees, casual employees, employers, and self-employed. The income information is based on the previous calendar year, 2013. The dollar/TL exchange rate was around 2 in 2013. The overall Turkey average annual income was 17,255 TL, which is around US\$8,627.

Source: TUIK (2014b).

Moreover, urbanization does not fully resolve the inequalities between men and women, such as inequalities in earned income.

Women's economic participation also varies based on educational attainment. According to recent statistics, the labor force participation rate for illiterate women is only $16 \%, 25.8 \%$ for women who received 
education below a high school degree, 31.9\% for high school graduates, $39.8 \%$ for women with vocational school degrees, and $71.3 \%$ for women with higher education (TUIK 2016a).

To better understand the relationship between urbanization and women's empowerment at the local level, we use an important indicator for each of the selected criteria for women's empowerment (education, economy, and politics). These are female literacy rates, female labor force participation rates, and the ratio of female local headpersons $\left(\right.$ muhtar $\left.^{7}\right)$ at the province level. Alternative indicators for each category (female secondary schooling, gender pay gap, insured workers gender gap, female governor ratio, female MP ratio at the province level) are also tested for the sake of robustness, all of which yield similar results. We take these indicators as dependent variables and run regressions taking urbanization as the independent variable. As shown in Figure 1, regression and scatterplot analyses show that urbanization has a positive impact on all of the selected women's empowerment indicators. Moreover, statistical tests indicate that urbanization has a very strong statistically significant impact on these measures. Particularly, urbanization has the biggest effect on the education variable. In fact, urbanization in and of itself explains $18.8 \%$ of the change in female literacy rates (as indicated by the $R^{2}$ figures). Likewise, it accounts for $6.4 \%$ of the change in female labor force participation rates and $10.3 \%$ of the change in the number of female local headpersons. In light of the local-level analyses, we can see that urbanization does improve women's lives at the economic and political fronts, yet it is evident that urbanization has the biggest impact on the educational aspect of women's empowerment for the Turkish case.

\section{A CLOSER LOOK AT THE EFFECTS OF URBANIZATION: THE VOICES OF TURKISH URBAN WOMEN}

Quantitative data on women's empowerment indicators, as facilitated in the previous section, give us a chance of benchmarking and cross-case comparison of the status of women (Chaudhuri 2013, 55). What is more, the indicators analyzed in the previous section are vital in understanding the state of women's empowerment, as our discussion in the introduction indicates. We believe, however, that instead of seeing

7. In the Turkish context, a muhtar is a locally elected headperson who deals with and leads the administrative works of local bodies and populace. 


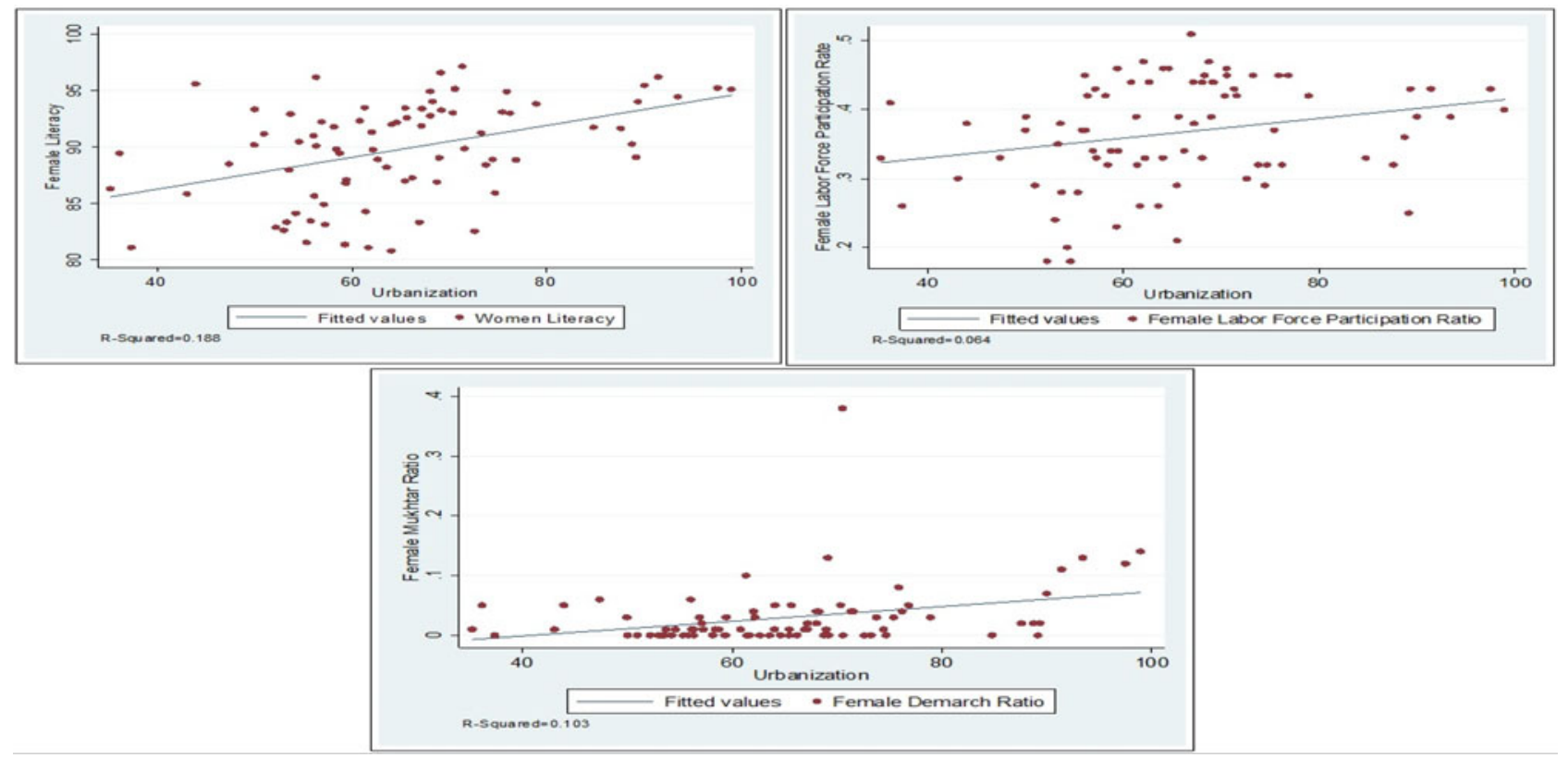

ב

FIGURE 1. Urbanization and women's empowerment at the province level. All of the regressions are done bivariately and at the province level $(N=81)$. Robust standard errors are used for the regressions.

Sources: TUIK, SGK, Ministry of Family and Social Policies. 
such indicators as women's empowerment in and of themselves, we need to see them as potential instruments for women's empowerment. It is best to treat such indicators as "necessary" conditions but not as "sufficient" ones.

The literature on women's empowerment has pointed to the utility of making analytical distinctions between preconditions and enabling factors. For example, Kabeer $(1999,437)$ defines empowerment as the ability to exercise choice and distinguishes between resources (preconditions), agency, and achievements (outcomes). According to Kabeer $(2005,15)$, "resources and agency make up people's capabilities: that is, their potential for living the lives they want. The term 'achievements' refers to the extent to which this potential is realized or fails to be realized; that is, to the outcomes of people's efforts." Kabeer (2005, 13) argues that education, employment, and political participation indicators are essential "resources" for "the achievement of gender equality and women's empowerment" and have "the potential to bring about positive changes in women's lives," but "it is the social relationships that govern access to the resource in question that will determine the extent to which this potential is realized." Drawing on Kabeer (1999), Goldman and Little $(2015,763)$ focus on empowerment "as an ongoing and iterative process, rather than something that can be measured as a final outcome." Thus, with Kabeer and Goldman and Little, we argue that the extent to which positive trends in these indicators empower women in real life remains to be tested.

We use this section to further investigate the extent to which the potential of women's empowerment hinted at by the educational, economic, and political indicators is realized, discussing the findings of an original, extensive survey. For this survey, we reached several women's organizations, namely, the Federation of Women's Organizations in Turkey (Türkiye Kadın Dernekleri Federasyonu), Women Entrepreneurs Association of Turkey (Türkiye Kadın Girişimciler Derneği), Uçan Süpürge, and Women's Cooperatives Association (Kadın Kooperatifleri Birliği), as well as women members of Union of Chambers of Turkish Engineers and Architects (Türk Mühendis ve Mimar Odaları Birliği). These organizations distributed the online survey (see Appendix B for survey questions) to their members throughout Turkey. The survey was a collection of multiple-choice and open-ended questions. Anonymity was ensured in the survey.

For the survey, 334 responses from 43 provinces were collected. These provinces include established metropolitan provinces (Ankara, Istanbul, Izmir) as well as newly urbanizing provinces (e.g., Adana, Gaziantep, 
Kayseri, Konya, etc.) (see Appendix C for province distribution). ${ }^{8}$ The sample as a whole is a maximum variation sample (Rivera, Kozyreva, and Sarovskii 2002; Seidman 2006) geographically as it spans all corners of the country. This enables us to make inferences that are representative of the larger population. The sample also presents an inverse U-shaped distribution vis-à-vis the age groups of the respondents, in which $19 \%$ are between 18 and 25; 39\% are between 26 and 35; 16\% are between 36 and $45 ; 14 \%$ are between 46 and 55; and $12 \%$ are over 56 . There is also sectoral diversity in the sample, in which $10 \%$ of the respondents are from academia, $20 \%$ from the public sector, $53 \%$ from industry, $6 \%$ from the service sector, $5 \%$ from arts and crafts, $3 \%$ are students, and the final $3 \%$ are housewives.

Another limitation of the quantitative data is that they do not capture inequality among women on the basis of women's backgrounds. To remedy this, our study narrows the scope of inquiry to a certain group of women. The survey comprises a nonrandom, purposive sample (Mosley 2013; Seidman 2006) consisting of women who are 18 years or older, who live in cities, and who are pursuing or have completed their undergraduate education or who pursued a postgraduate degree. ${ }^{9}$ With this survey, we examine what cities have to offer well-educated, urban women and what prospects and challenges lie ahead of them. The justification for the sample selection is as follows: if we observe problems even in this seemingly well-to-do and ostensibly empowered women profile, the barriers faced by such women would easily multiply when lower strata of society are reached. To this end, the findings from this "least likely" sample can be generalized for many urban women throughout Turkey and help us find out what cities in Turkey can and cannot offer with regard to women's empowerment in the areas of education, economics, and politics.

8. The classification between already metropolitan provinces and newly urbanizing provinces is based on the historical trajectories of urbanization rates in Turkey. On the one hand, Istanbul and Izmir have long been urban centers since the Ottoman Empire and continued to be metropolitan hubs in the Turkish Republic, while Ankara became the nation's capital after the proclamation of the Turkish Republic in 1923 and rapidly urbanized afterward. The newly urbanizing provinces, on the other hand, are localities that have urbanized since the 1980s and 1990s, when Turkish society started to become predominantly urban (see Table 1). Istanbul, Ankara, and Izmir are still the biggest provinces in Turkey based on their populations around 14.8 million, 5.3 million, and 4.2 million, respectively, and still receive net positive migration, whereas the biggest provinces in the latter group are Bursa, Antalya, and Adana, with populations around 2.9 million, 2.3 million, and 2.2 million, respectively (TUIK 2016b).

9. As a benchmark, the overall percentage of population (aged 25 and over) who hold university degrees is $15.5 \%$. This percentage is $17.9 \%$ for men, whereas only $13.1 \%$ of women hold university degrees (TUIK 2017). 


\section{Educational Empowerment}

Survey findings confirm that urbanization leads to betterment in educational empowerment. In all, 58\% of respondents indicated that urbanization has brought about major enhancements in their education, whereas only $11 \%$ responded negatively. To the open-ended question, "Have you or any of your close relatives (like your mother or grandmother) ever experienced migration from rural to urban areas? If yes, have you witnessed that urbanization has enhanced the opportunities of women regarding education, health, economy, and politics?," all of the respondents who witnessed urbanization personally (either themselves or their mothers, grandparents etc.) reported an increase in such opportunities. The respondents especially stressed the positive influence of urbanization on education. They noted that the good education of their mothers was attributable to migrating to the city. For instance, one respondent compared the conditions of her cousins before and after they moved to the city:

Two of my cousins had to drop out of school and stay at home after high school when they were in the town. When the whole family moved to Ankara they started working and they found their education insufficient. As a result, they completed their education.

Another respondent compared her fate to those who stayed in the village:

My father moved to the city when he was young. As a result, I am a university professor, those who stayed in the village continued to get married and have children.

Respondents noted, however, that educational empowerment needs to be backed by the support of the family. Only then can the positive effects of urbanization be achieved. Some of them, especially addressing the migrations from the East to the West, also stressed that there are integration and adaptation problems that need to be addressed.

\section{Economic Empowerment}

Regarding economic empowerment, the majority of the respondents $(84 \%)$ believe that they have economic freedom. However, the survey respondents underlined the inequalities in the economic arena. When asked about the single thing they lack the most in the workplace, the respondents highlighted two major problems. One is related to the workplace itself, 
whereas the other one is related to the family and the chores attributed to women in the private sphere and their reflections in their careers. In the workplace, respondents complained about the male-dominated work environment. They stressed that there is gender inequality in every area of their work; they are not respected because of their gender, women are not given administrative duties, and there are gender stereotypes and prejudices. The respondents said that they have to fight to be taken seriously, to be respected, and to have themselves heard, even if they are better educated and have higher qualifications than their male coworkers. They also reported that they are expected to be "nice," "confirming," "patient," etc. One of the respondents summarized the gender inequalities at the workplace very well:

My biggest problem in the workforce is that women are still seen as secondclass citizens and no matter what our education level is, there are still men who are offended by getting orders from women.

The respondents revealed that women are still relegated to certain jobs. They complained that there are no or very small number of women at higher ranks. One respondent also noted that even though she is an architect, people entering the office mistake her for the secretary.

Although the majority (95\%) of the respondents believe that they have a say in their household (such as on the number of children they will have), they find it difficult to balance life and work in face of high domestic expectations from them. Many respondents used phrases such as "feeling insufficient," "running out of time," and "being unable to focus" that indicate the problem. Respondents maintain that having to fulfill all household duties and taking care of children while trying to fulfill job responsibilities take a toll on them. They also stated that household chores are not equally shared by their spouses. As one of the respondents succinctly explained,

We are not facing the same conditions with men when it comes to child care and household chores. We are doing all the things at home that a housewife does and when we come to work, we compete with the men in the market. That means we practically work two shifts and that is back-breaking.

Meanwhile, women also complained that there are not enough and affordable day care facilities for children to take away the burden of finding child care. This shows that better education and better-paying jobs do not automatically give women equal status as men. Even though these factors make these women better off than women who lack such 
opportunities, women still have to struggle with patriarchy in their everyday lives both at work and at home.

\section{Political Empowerment}

As it is the case with the economic sector, women feel disadvantaged when it comes to politics. In all, $52 \%$ of the respondents indicated that they would like to participate more in politics (38\% were happy with their political participation, while only $10 \%$ would like to participate less). When asked about the biggest barrier in entering politics, respondents cited taboos about female participation in politics. They blamed the male-dominant system and maintained that traditional roles attributed to women such as motherhood and being a housewife make it harder for women to enter into politics. Nearly all respondents argued that family, work, and children do not leave any time for politics. As one respondent put it,

Women's responsibilities at work and at home are so much and men are so stingy in sharing such responsibilities that there is no energy and time left for active politics.

Women are in fact so exhausted by their time being taken up by daily chores and responsibilities that an overwhelming majority of them answered the open-ended question that asked, "What is the biggest difficulty you face as a woman?" as carrying the responsibilities at work as well as at home. Women also stated that they feel torn between their careers and raising children. Similar to the answers given to political participation, they repeated that men are not taking over a sufficient and fair share in housework duties. As one respondent declared,

They expect us to be career women, mothers, wives and housewives at the same time. I yet have to see a man who can do all these at once.

As a result of such unrealistic expectations, women feel left alone to shoulder duties in different spheres of life, and this leaves no resources left for politics. As one women (similar to many others) put it,

The first barrier is the male-dominant society. Because men lead even political issues related to women, they always see themselves as priorities. The second barrier is child care. You cannot say to anyone "here, take care of my kid, I am going to do politics."

As in the case of workforce, they complained that lack of trust and respect as well as not being taken seriously also play a huge role in hindering their participation in politics. Women also mentioned men, especially their 
fathers, husbands, and boyfriends, as the biggest hurdle in front of their political participation. One respondent stated the following:

I think that men are afraid of women. They believe that if women successfully exist in every field of active life (work and production), the basic needs of men will be seriously wounded. That is why they prefer women to exist at home and as mothers.

The themes that surfaced from our specific questions show us that the limitations women face in different realms of life are indeed intertwined and require an integral approach to the question at hand. When women talk about the biggest difficulties in their lives, they mention time poverty, gendered household expectations, as well as belittlement and not been taken seriously. They feel that they constantly have to prove themselves. As a result, many feel that they have no time left to devote for themselves, realize their full potential at work or enter politics.

\section{Complexities of Urbanization}

As shown thus far, urbanization provides certain benefits for women, but the picture is far from straightforward. Our survey reveals that there are complexities to be taken into consideration when discussing the gains of urbanization, even for educated women. In addition to time poverty, gender roles that assign women to the private realm and the need to prove themselves on a daily basis, as well as daily concerns regarding the physical environment, affect women's prospects both in the political and economic realm as they prevent women from being publicly more active, outspoken, and outgoing. With the open-ended question asking about women's greatest concern, the survey clearly shows that one of the biggest challenges to the self-actualization of women in cities is their feeling of threat and fear. Earlier research has shown that urban women are at risk of gender-based violence in the forms of abduction, rape, and/ or murder ("femicide") in their neighborhoods and in cities at large. This risk is especially dire for young women, women who "transgress heteronormative boundaries such as those who live "independently," and in localities without adequate infrastructure (street lighting) and effective policing (Chant and Datu 2015, 51-52). As Chant and Datu (2015, 53-54) argue, limited or restricted mobility seriously jeopardizes women's prospects of "exiting poverty and gaining prosperity" and attaining empowerment. It is important that women can go out alone and feel safe doing so. There are practical reasons for this: to work, to 
escape domestic abuse, to go to places, and to build new networks of solidarity, among others.

In our research, almost all of the respondents indicated that they do not feel safe and comfortable while walking alone in their neighborhoods and in the city. Women said that they try to find ways to get around this problem and are even willing to pay higher costs for this. Women who live close to university campuses and in gated communities feel relatively more secure. Respondents are willing to pay higher rents. The locations and times at which respondents feel safe are very limited: during the day, places they know, or places that are crowded. Almost all respondents stated that they feel insecure at dark. They complained about insufficient street lights at night. Words such as "fear," "danger," and "threat" were used by the majority of respondents. Many mentioned men as the source of threat. They are specifically threatened by the possibility of verbal and physical harassment and rape. They do not believe that the state and laws protect them sufficiently against such crimes. They also mentioned fear of being mugged and attacked by drug addicts. Knowing the neighborhood in which they live gives partial comfort to some of the respondents, whereas others feel threatened by the social pressure they feel from the environment.

Gender inequality and harassment at work are also common concerns. Women noted that they are actually afraid of harassment and even rape, and many stressed once more that they do not feel safe on the streets and on public transportation because of that. One important reason for that, according to the respondents, is the fact that culturally it is assumed that women on the streets, especially at nights, are assumed to be willing to receive sexual advances. When asked whether there is anything they want to add to the survey, many women stressed that men need to be educated on issues related to women so that they better understand gender equality and its implications.

In addition to the accounts of women themselves, more systemic differences are revealed through the analysis of our data. One such striking difference became visible in our comparison between old and new urban centers. In our comparison, we examined whether there are significant differences in respondents' views in already metropolitan provinces (Ankara, Istanbul, and Izmir) versus other, more recently urbanizing cities. The observation numbers on both groups $\left(n_{1}=220\right.$, $n_{2}=114$ ) enable us to run means-difference tests on important questions about women's empowerment, shown in Table 4. 
Table 4. Means-difference tests between already and newly urbanized provinces

\begin{tabular}{|c|c|c|c|c|c|}
\hline & $\begin{array}{l}\text { Education } \\
\text { Level }\end{array}$ & $\begin{array}{c}\text { Urban Centers } \\
\text { Contributing to } \\
\text { Education }\end{array}$ & $\begin{array}{l}\text { Economic } \\
\text { Freedom }\end{array}$ & $\begin{array}{l}\text { Getting Permission } \\
\quad \text { to Go Outside }\end{array}$ & $\begin{array}{c}\text { Willing to Participate } \\
\text { More in Politics }\end{array}$ \\
\hline $\begin{array}{l}\text { Already metropolitan provinces } \\
\text { (Ankara, Istanbul, Izmir) }\end{array}$ & $\begin{array}{l}3.45 \\
(0.50)\end{array}$ & $\begin{array}{l}3.91 \\
(0.77)\end{array}$ & $\begin{array}{l}0.88 \\
(0.33)\end{array}$ & $\begin{array}{l}1.92 \\
(0.27)\end{array}$ & $\begin{array}{l}3.48 \\
(1.10)\end{array}$ \\
\hline Other provinces $(40)$ & $\begin{array}{l}3.26 \\
(0.44)\end{array}$ & $\begin{array}{l}3.08 \\
(0.78)\end{array}$ & $\begin{array}{c}0.79 \\
(0.41)\end{array}$ & $\begin{array}{l}1.72 \\
(0.45)\end{array}$ & $\begin{array}{l}3.69 \\
(1.04)\end{array}$ \\
\hline$t$-difference & $3.57^{*}$ & $-9.26^{*}$ & $-2.02^{* * 2 *}$ & 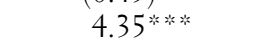 & $1.72^{*}$ \\
\hline
\end{tabular}


First, education levels are significantly higher for women in older metropolitan areas than those in newly urbanizing provinces. Furthermore, those in the former group believe that urban centers contribute to their education more profoundly. Statistical tests show that this is the greatest difference between these women and women in newly urbanizing cities. On the economic front, the former group also shows higher percentages of feelings of economic freedom than the latter group. Women in Ankara, Istanbul, and Izmir also do not have to get permission from their husbands or other family members more predominantly than the ones in other cities. On the political front, women in other provinces would like to participate more in politics than women in Ankara, Istanbul, and Izmir. Women in already metropolitan cities feel more empowered with regard to education, economics, and politics, whereas women in other, newly urbanizing cities are still in search for more empowerment on all aspects.

How can we interpret these findings on the difference between old urban centers and new ones? One possible interpretation is related to differing definitions of modernity in Turkey. Modernity in Turkey has been understood as cultural modernity and Westernization up until around the 1980s (Buğra and Savaşkan 2014, 30; Kasaba 2008, 2). The earlier modernization project put education and raising the status of women at the center. While such definitions were top down and insufficiently pluralistic (Göle 1997, 49), they nevertheless put a lot of emphasis on women's education and visibility in the public sphere. Over time, such notions of modernity have been replaced by alternative visions of modernity that are based more on economic development and industrialization (Göle 1993, 201). In addition to local factors that affected this transformation, the rise of neoliberal economic understanding in the world and its repercussions on the Turkish case can also be seen as responsible for the primacy of economics and comparable negligence of women's rights and empowerment. What is more, one can argue that older urban centers still provide more employment facilities, civil society organizations, political associations, as well as educational opportunities. New cities still have to bring the level of employment, education, and associational capacity provided for women to the same level as their level of economic development.

At the macro level, the broader political context is vital in interpreting the findings of this article. Patriarchy and gender inequality is reproduced daily in Turkish politics. Top politicians, especially Recep Tayyip Erdoğan, frequently situate women in an inferior position to men 
and speak in their name in terms of how many children they should have or the way they should give birth (see, e.g., CNN Turk 2014). In fact, the current political leadership derives its power from putting itself in a position of an all-knowing patriarch, which especially hurts women (Ugur-Cinar 2017). Overall, it is not surprising, then, that the Gender Gap Index that measures gender-based gaps in access to resources and opportunities, ranks Turkey 130th out of 144 countries (World Economic Forum 2016).

As briefly stated at the start of this article, women have been negatively impacted by the dual threats of conservatism and neoliberalism under AKP rule (Coşar and Yeğenoğlu 2011), whose policies both expose women to market insecurities and reinforce their domestic roles (Buğra 2014; Yllmaz Şener 2016). Women are not recognized as such, but rather are seen as domestic beings, meaningful only within the familial context. A striking example is the fact that the General Directorate of Women's Status and Problems, established in 1991 as a requirement of the Convention on the Elimination of All Forms of Discrimination Against Women process to monitor gender equality, was abolished in 2011 and replaced by the Ministry of the Family and Social Policies (Kandiyoti 2016, 107).

The attitude of the state toward women has major consequences for the daily lives of women, most of which have been demonstrated by the survey results. For example, women's feeling of insecurity needs to be read in line with the fact that the political system does not make it a public policy priority to create safe public and private spaces for women. In Turkey, violence against women is not fought with deterrent majors by the state. Especially at the implementation phase of laws, there is much lenience toward perpetuators. As Kandiyoti $(2016,109)$ notes, "a multitude of rapists and killers get off lightly benefiting from so-called 'reductions for good behavior,' for nothing more consequential than having a respectful bearing, wearing a tie to court, expressing regret or pleading intolerable provocation to their male honor."

Another concrete example that causally links the complaints of the respondents with the broader framework concerns the issue of lack of adequate day care facilities. The regulations in Turkey stipulate that businesses employing more than 150 women must provide day care facilities (Buğra 2014, 154). Because the regulation does not cover all employees but singles out women only, it actually provides a disincentive for the employment of women. As Buğra also argues (2014, 154), "public provision of day care does not figure in the list of the priorities of the government policy agenda." 
All in all, given the overwhelming political pattern, it is not surprising that women's issues converge with one another even in the open-ended survey questions. Our findings regarding women's concerns about patriarchal norms, time poverty, fear of the physical environment, diminishing prospects in new urban centers, as well as the political context illustrate that unless broader institutional, structural, cultural issues are addressed, the gains of urbanization will be moderate at best.

\section{Findings in Comparative Perspective}

Our sample consists of well-educated, better-off, and mostly nonmigrant urban women. From the findings of this sample, we can make comparisons with the polar opposite sector of the urban population. From the existing literature, we know that less educated, poor urban women face distinctive challenges not voiced by our sample. For example, in the case of urban "unskilled" women, there is a large informal job market lacking health and retirement benefits, as well as the minimum-wage guarantee of the formal sector (Cinar 1994, 369). In addition, "unskilled" women are deterred from taking jobs in the formal market because they cannot get permission from their husbands or fear sexual harassment that can result from working outside the home (Buğra 2014, 152; Cinar 1994, 372). Instead, these women accept "piece work at home or prefer to work in small workshops located close to their neighborhood and owned by relatives or others with a connection to the family." Cinar $(1994,377)$ also finds that a lot of these women have been discouraged from looking for jobs in the formal sector and have given up. Finally, as Erman, Kalaycıoğlu, and Rittersberger-Tılıç (2002, 398) show, low levels of education of many migrant women and their lack of formal work experience put them at a disadvantage in the urban labor market.

In addition to the different conditions faced by these two different groups of women, but closely related to that, are the observed attitudinal differences of the two groups of women toward patriarchal norms and gender roles. Osmani's $(1998,72)$ research on poor women in Bangladesh illustrates how these women kept accepting certain gender roles that made them inferior to men, even after their access to bank credit improved their economic conditions. Similar to that, Erman, Kalaycıoğlu, and Rittersberger-Tılıç $(2002,400)$ find that some of the migrant women in their research "tend to undervalue their contributions 
to their families [and]. . . continue to see their husbands as the "heads of the family,' and accept their own subordinate positions in their families." The authors further observe that these migrant women, mostly employed in the informal sector, "tend to define themselves merely in terms of their families, as mothers and wives" and "they behave submissively to their husbands and treat them with deference" (Erman, Kalaycıŏlu, and Rittersberger-T1lıç 2002, 406-7) In a similar vein, Cinar (1994, 371) finds that the migrant, lower-income women she interviewed did not regard home work as "work." Instead, they regarded "their work as temporary and their knitting as a hobby, even though some had done this for over 10 years." What is more, Cinar $(1994,377)$ reports that these women were also proud of the fact that their husbands did not let them work outside the home.

In contrast, women in our sample seem to be much more bothered, or at least more vocal about the inequalities they face as women. They are not happy that housework is seen as their duty and that men want to put them into certain gender roles. What could be the reason behind this divergence in attitude between two different groups of urban women? First, the divergence can be attributed to the capabilities of women in both groups. Because women with better working conditions have more economic freedom and social benefits, they can challenge the patriarchal relations in which they live without facing the kind of problems lower class women do. Second, this difference supports the finding in the literature that female labor force participation and education both play an important role in raising the political consciousness of women (Wyndow et al., 2013: 37). The nature of the work is also important here. In the formal sector, women who face similar discriminations can come together and discuss their problems, which can raise awareness of the issues they face (Ross 2008; Wyndow, $\mathrm{Li}$, and Mattes 2013, 37). As Ross $(2008,107)$ argues, the fewer women work outside home, the less they are "likely to exchange information and overcome collective action problems."

Our findings, along with the comparison to women in other sectors of occupation in the Turkish society, show that urbanization is experienced differently by different groups. This includes different responses of women in the informal sector as well as differences even within our own sample. A case in point is the reminder of some of our respondents that migration from the East to the West caused integration and adaptation problems which have not been faced by women who did not go through such experiences. Given the geographic distribution, one could argue 
that a significant number of such women are Kurdish in origin. These points invite further studies within an intersectional approach that delves deeper in the repercussions of the effects of urbanization on women's empowerment.

\section{CONCLUDING REMARKS}

Throughout the world, urbanization leads both men and women to adapt to and form new class and communal identities as well as new or shifting gender roles and regimes (Hammad 2016, 1-2). On the other hand, systematically structured forms of gender inequality are hard to eradicate. Patriarchal norms, structures, and practices evolve to different dimensions and sites (such as from household to workplace) rather than totally being eliminated (Moghadam 1996, 5). The sample of educated, urban women analyzed in the Turkish case has shown that while these women have experienced advancements in their well-being and independence on some fronts (such as gaining economic independence, attaining better education), they still face many hardships in their lives (such as challenges at the workplace, being torn between work and family and not being able to enter politics) that hinder their empowerment because of lingering and evolving patriarchal norms and institutions.

Our findings support the claim that although new, advanced patterns of women engagement in education, economics, and politics show high promise toward a more egalitarian set of gender relations (Moghadam 1998, 11), without the transformation of institutions and relations that sustain gender inequalities, women's access to economic, political, and educational resources would not be sufficient for them to become fully empowered. The Turkish case shows us that societal transformations such as urbanization have an imprint on the fate of women yet further enhancements in economic affluence and gender equality can only be realized with inclusive economic institutions and democratic political institutions. Appropriate public policies and a more egalitarian gender contract, "predicated on women's full citizenship, recognition of their economic contributions, entitlement to social benefits, gender-based social movements and political mobilizations" (Moghadam 1998, 23435), are critical to ensure fulfillment of women's empowerment at the individual, household, and societal levels in the world. This would mean, for example, more resource allocation to affordable schooling, health care (Moghadam 2016, 220), and day care for children. 
This also brings us to a related point on women's empowerment indicators. As we stated in the article, these indicators are an important tool in giving us an overall idea about the resources potentially available to women. But in addition to individual level indicators that measure women's empowerment, we also need to push for a social, legal, and political framework that collectively empowers women. The conservative-neoliberal alliance that worsened the condition of Turkish women and the fact that newly urbanizing centers cannot catch up with the old ones show us that there are barriers at the legal and political level that women cannot overcome individually. Our findings thus echo the call in the feminist literature to understand women's empowerment as a process that includes "growth of individual awareness, self-esteem, critical consciousness, and capacity building" as well as "collective engagement, political mobilization, and transformative social action" (Biewener and Bacqué 2015, 67). This is also key for mobilizing women beyond class lines and raise awareness among them that goes beyond occupational and educational divides. As Beşpınar (2010, 531) argues, the widening socioeconomic gap between different classes of women, the restructuring of workplaces through home-based production, as well as diminished unionization have so far led to the isolation of women and have made it more difficult for women to realize how collective their problems are and that they need to strategize and mobilize collectively.

Urban women, though still disempowered in a lot of ways, create and learn to inhabit new norms, practices, and societal, economic, political, and gender relationships (Hammad 2016, 12). Our study contributes to our understanding of how urban women within the constants and evolutions of societal and especially gender relations fit into different urban contexts and how they interact with these relations and contexts to become (or fail to become) more emancipated and empowered.

\section{SUPPLEMENTARY MATERIAL}

To view supplementary material for this article, please visit https:/doi.org/ 10.1017/S1743923X18000028.

Kursat Cinar is European Union Marie Curie Fellow in the Department of Political Science at Bilkent University, Turkey: kursat.cinar@bilkent.edu.tr; Meral Ugur-Cinar is Assistant Professor of Political Science at Bilkent University:meral.ugur@bilkent.edu.tr. 


\section{REFERENCES}

Abadian, Sousan. 1996. "Women's Autonomy and Its Impact on Fertility." World Development 24 (12): 1793-1809.

Afshar, Haleh, ed. 1998. Women and Empowerment: Illustrations from the Third World. New York: St. Martin's Press.

Alexander, Amy C. 2012. “Change in Women's Descriptive Representation and the Belief in Women's Ability to Govern: A Virtuous Cycle.” Politics ङ Gender 8 (4): 437-64.

Almeleh, Naomi, Steven Soifer, Naomi Gottlieb, and Lorraine Gutierrez. 1993. "Women's Achievement of Empowerment through Activism in the Workplace.” Affilia 8 (1): 2639.

Altan-Olcay, Özlem. 2014. "Entrepreneurial Subjectivities and Gendered Complexities: Neoliberal Citizenship in Turkey," Feminist Economics 20 (4): 235-59.

Ashraf, Nava, Dean Karlan, and Wesley Yin. 2009. "Female Empowerment: Impact of a Commitment Savings Product in the Philippines." World Development 38 (3): 333-44.

Banks, Nicola. 2013. "Female Employment in Dhaka, Bangladesh: Participation, Perceptions and Pressures." Environment and Urbanization 25 (1): 95-109.

Beşpınar, F. Umut. 2010. "Questioning Agency and Empowerment: Women's WorkRelated Strategies and Social Class in Urban Turkey.” Women's Studies International Forum 33 (6): 523-32.

Biewener, Carole, and Marie-Hélène Bacqué. 2015. "Feminism and the Politics of Empowerment in International Development." Africa \& Francophonie 6 (2): 58-75.

Boserup, Ester. 1970. Woman's Role in Economic Development. London: Allen \& Unwin.

Buğra, Ayse. 2014. "Revisiting the Wollstonecraft Dilemma in the Context of Conservative Liberalism: The Case of Female Employment in Turkey." Social Politics 21 (1): 148-66.

Buğra, Ayse, and Osman Savaşkan. 2014. New Capitalism in Turkey: The Relationship between Politics, Religion and Business. Cheltenham: Edward Elgar.

Burnet, Jennie F. 2011. "Women Have Found Respect: Gender Quotas, Symbolic Representation, and Female Empowerment in Rwanda." Politics \& Gender 7 (3): $303-34$.

Chant, Sylvia. 2013. “Cities through a 'Gender Lens': A Golden 'Urban Age' for Women in the Global South?” Environment and Urbanization 25 (1): 9-29.

Chant, Sylvia, and Kerwin Datu. 2015. "Women in Cities: Prosperity or Poverty? A Need for Multi-dimensional and Multi-spatial Analysis." In The City in Urban Poverty, eds. Charlotte Lemanski and Colin Marx. Basingstoke: Palgrave Macmillan, 39-63.

Charrad, Mounira M. 2009. "Kinship, Islam or Oil: Culprits of Gender Inequality?” Politics and Gender 5 (4): 546-53.

Chaudhuri, Sanjukta. 2013. "A Life Course Model of Human Rights Realization, Female Empowerment, and Gender Inequality in India." World Development 52: 55-70.

Choo, Hae Yeon. 2012. “The Transnational Journey of Intersectionality.” Gender \& Society 26 (1): 40-45.

Cinar, E. Mine. 1994. "Unskilled Urban Migrant Women and Disguised Employment: Home-Working Women in Istanbul, Turkey." World Development 22 (3): 369-80.

Cindoğlu, Dilek, and Şule Toktaş. 2002. "Empowerment and Resistance Strategies of Working Women in Turkey." European Journal of Women's Studies 9 (1): 31-48.

CNN Turk. 2014. "Erdoğan: Kadın ve erkeğin eşit olması fitrata ters" [Erdoğan: Malefemale equality is against nature]. November 24. http:/www.cnnturk.com/haber/ turkiye/erdogan-kadin-ve-erkegin-esit-olmasi-fitrata-ters (accessed February 21, 2018). [in Turkish]

Coşar, Simten, and Metin Yeğenoğlu. 2011. "New Grounds for Patriarchy in Turkey? Gender Policy in the Age of AKP." South European Society and Politics 16 (4): 555-73. 
Dogan News Agency. 2014. “TÜİK: Kent-kır ayrımı kalmadı” [TUIK: There is no difference between urban and rural any more]. April 15. http://www.dha.com.tr/tuik-kent-kirayrimi-kalmadi_648700.html (accessed February 21, 2018). [in Turkish]

Elmas, Gülen. 2004. "Women, Urbanization and Regional Development in Southeast Anatolia: A Case Study for Turkey." Turkish Studies 5 (3): 1-24.

Erman, Tahire, Sibel Kalaycıoğlu, and Helga Rittersberger-Tılıç. 2002. "Money-Earning Activities and Empowerment Experiences of Rural Migrant Women in the City: The Case of Turkey." Women's Studies International Forum 25 (4): 395-410.

Eswaran, Mukesh. 2002. "The Empowerment of Women, Fertility, and Child Mortality: Towards a Theoretical Analysis." Journal of Population Economics 15 (3): 433-54.

Geerts, Evelien, and Iris van der Tuin. 2013. "From Intersectionality to Interference: Feminist Onto-epistemological Reflections on the Politics of Representation." Women's Studies International Forum 41 (3): 171-78.

Goldin, Claudia. 1995. "The U-Shaped Female Labor Force Function in Economic Development and Economic History." In Investment in Women's Human Capital, ed. T. Paul Schultz. Chicago: University of Chicago Press, 61-90.

Goldman, Mara J., and Jani S. Little. 2015. "Innovative Grassroots NGOs and the Complex Processes of Women's Empowerment: An Empirical Investigation from Northern Tanzania." World Development 66: 762-77.

Göle, Nilüfer. 1993. "Engineers: "Technocratic Democracy." In Turkey and the West: Changing Political and Cultural Identities, eds. Metin Heper, Ayse Öncü, and Heinz Kramer. London: I.B. Tauris, 199-218.

- 1997. "Secularism and Islamism in Turkey: The Making of Elites and CounterElites." Middle East Journal 51 (1): 46-58.

Haile, Hirut Bekele, Bettina Bock, and Henk Folmer. 2012. "Microfinance and Female Empowerment: Do Institutions Matter?” Women's Studies International Forum 35 (4): $256-65$.

Hammad, Hanan. 2016. Industrial Sexuality: Gender, Urbanization, and Social Transformation in Egypt. Austin: University of Texas Press.

Inglehart, Ronald, and Pippa Norris. 2003. Rising Tide: Gender Equality and Cultural Change around the World. Cambridge: Cambridge University Press.

Inkeles, Alex, and David H. Smith. 1974. Becoming Modern: Individual Change in Six Developing Countries. Cambridge, MA: Harvard University Press.

Janssens, Wendy. 2009. "Women's Empowerment and the Creation of Social Capital in Indian Villages." World Development 38 (7): 974-88.

Kabeer, Naila. 1999. "Resources, Agency, and Achievements: Reflections on the Measurement on Women Empowerment." Development and Change 30 (3): 435-64.

— . 2001. "Conflict over Credit: Re-evaluating the Empowerment Potential of Loan to Women in Rural Bangladesh." World Development 29 (1): 63-84.

- 2005. "Gender Equality and Women's Empowerment: A Critical Analysis of the Third Millennium Development Goal." Gender \& Development 13 (1): 13-24.

Kandiyoti, Deniz. 1982. "Urban Change and Women's Roles: An Overview and Evaluation.” In Sex Roles, Family, and Community in Turkey, ed. Çiğdem Kagitcibasi. Bloomington: Indiana University Press, 101-20.

_ 1987. "Emancipated but Unliberated? Reflections on the Turkish Case." Feminist Studies 13 (2): 317-38.

—. 1988. "Bargaining with Patriarchy." Gender \& Society 2 (3): 274-90.

2016. "Locating the Politics of Gender: Patriarchy, Neo-Liberal Governance and Violence in Turkey." Research and Policy on Turkey l (2): 103-18.

Karakaş, Burcu. 2016. "Kadının bir soyadı 'zaferi' daha: Çözüm mahkemede değil, yasa değişikliğinde" [Another victory for women on last names: The solution is in 
changing laws, not in courts]. April 19. http://www.diken.com.tr/kadinin-bir-soyadizaferi-daha-cozum-mahkemede-degil-yasa-degisikliginde/ (accessed February 21, 2018). [in Turkish]

Kasaba, Reşat. 2008. “Introduction.” In The Cambridge History of Turkey, Volume 4: Turkey in the Modern World, ed. Reşat Kasaba (Ed.) Cambridge: Cambridge University Press.

Kitschelt, Herbert, and Steven I. Wilkinson, eds. 2007. Patrons, Clients, and Policies: Patterns of Democratic Accountability and Political Competition. Cambridge: Cambridge University Press.

Lerner, Daniel. 1958. The Passing of Traditional Society: Modernizing the Middle East. New York: Free Press.

Lind, Amy. 1997. "Gender, Development and Urban Social Change: Women's Community Action in Global Cities." World Development 28 (9): 1205-23.

Lipset, Seymour Martin. 1959. "Some Social Requisites of Democracy: Economic Development and Political Legitimacy." American Political Science Review 53 (1): 69-105.

Mann, Susan Archer. 2012. "Intersectionality Theories." In Doing Feminist Theory: From Modernity to Postmodernity, by Susan Archer Mann. Oxford: Oxford University Press, $160-208$.

Mitra, Arup. 2005. "Women in the Urban Informal Sector: Perpetuation of Meagre Earnings." Development and Change 36 (2): 291-316.

Moghadam, Valentine M., ed. 1996. Patriarchy and Economic Development: Women's Positions at the End of the Twentieth Century. Oxford: Clarendon Press.

- 1998. Women, Work, and Economic Reform in the Middle East and North Africa. London: Lynne Rienner.

— 2016. "Women and Democracy after the Arab Spring: Theory, Practice, and Prospects." In Empowering Women after the Arab Spring, eds. Marwa Shalaby and Valentine M. Moghadam. London: Palgrave Macmillan, 193-216.

Mosley, Layna. 2013. “Just Talk to People’? Interviews in Contemporary Political Science.” In Interview Research in Political Science, ed. Layna Mosley. Ithaca, NY: Cornell University Press, $1-28$.

Osmani, Lutfun N. K. 1998. "The Grameen Bank Experiment: Empowerment of Women through Credit." In Women and Empowerment: Illustrations from the Third World, ed. Haleh Afshar. New York: St. Martin's Press, 67-85.

— 2007. "A Breakthrough in Women's Bargaining Power: The Impact of Microcredit." Journal of International Development 19 (5): 695-716.

Pampel, Fred, and Kazuko Tanaka. 1986. "Economic Development and Female Labor Force Participation: A Reconsideration.” Social Forces 64 (3): 599-619.

Patil, Vrushali. 2013. "From Patriarchy to Intersectionality: A Transnational Feminist Assessment of How Far We've Come.” Signs 38 (4): 847-67.

Pitt, Mark M., and Shahidur R. Khandker. 1996. "The Impact of Group-Based Credit Programs on Poor Households in Bangladesh: Does the Gender of Participant Matter?" Journal of Political Economy 106 (5): 958-95.

Psacharopoulos, George, and Zafiris Tzannatos. 1991. "Female Labor Force Participation and Education." In Essays on Poverty, Equity and Growth, ed. George Psacharopoulos. Oxford: Pergamon Press, 266-90.

Rivera, Sharon Werning, Polina M. Kozyreva, and Eduard G. Sarovskii. 2002. "Interviewing Political Elites: Lessons from Russia." PS: Political Science and Politics 35 (4): $683-88$.

Ross, Michael L. 2008. "Oil, Islam, and Women.” American Political Science Review 102 (1): $107-23$.

Seidman, Irving. 2006. Interviewing as Qualitative Research: A Guide for Researchers in Education and the Social Sciences. 3rd ed. New York: Teachers College Press. 
Tansel, Aysit. 2002. "Economic Development and Female Labor Force Participation in Turkey: Time-Series Evidence and Cross-Province Estimates." Economic Research Center Working Papers in Economics, 01/05.

Turkish Statistical Institute (TUIK). 2014a. The Revision in the Definitions of Rural and Urban http://www.resmiistatistik.gov.tr/?q=tr/content/18-k\%C4\%Blrkent-tan\%C4\% Blm\%C4\%Bln\%C4\%Bln-revizyonu (accessed February 22, 2018).

—. 2014b. Turkey in Statistics. http://www.turkstat.gov.tr/IcerikGetir.do?istab_id=5 (accessed February 22, 2018).

— . 2016a. Women in 2015. http://www.tuik.gov.tr/PreHaberBultenleri.do?id=21519 (accessed February 22, 2018).

- 2016b. Major Statistics. http://www.tuik.gov.tr/UstMenu.do?metod=temelist (accessed February 22, 2018).

- 2017. Women in 2016. http://www.tuik.gov.tr/PreHaberBultenleri.do?id=24643 (accessed February 22, 2018).

Ugur-Cinar, Meral. 2014. "Construction of Gender and National Identity in Turkey: Images of the First Lady in the Turkish Media (2002-7)." Middle Eastern Studies 50 (3): $482-92$.

- 2017. "Embedded Neopatrimonialism: Patriarchy and Democracy in Turkey." Social Politics: International Studies in Gender, State \& Society 24 (3): 324-43.

United Nations. 2015. "UN Sustainable Development Goals." http://www.who.int/ mediacentre/events/meetings/2015/un-sustainable-development-summit/en/ (accessed December 19, 2017).

Weber, Olaf, and Adnan Ahmad. 2014. "Empowerment Through Microfinance: The Relation between Loan Cycle and Level of Empowerment." World Development 62: 75-87.

World Economic Forum. 2016. “The Global Gender Gap Report 2016.” http://reports. weforum.org/global-gender-gap-report-2016/rankings/ (accessed February 21, 2018).

Wyndow, Paula, Jianghong Li, and Eugen Mattes. 2013. "Female Empowerment as a Core Driver of Democratic Development: A Dynamic Panel Model from 1980 to 2005." World Development 52: 34-54.

Yllmaz Sener, Meltem. 2016. "Conditional Cash Transfers in Turkey: A Case to Reflect on the AKP's Approach to Gender and Social Policy." Research and Policy on Turkey 1 (2): $164-178$. 